\title{
„A HÓJAGOS HIMLŐNEK BÉ-OLTÁSÁRÓL", AVAGY TANULMÁNYOK A HIMLŐOLTÁS KALANDOS MÚLTJÁBÓL
}

Ritkán adódik, hogy történeti, különösen orvostörténeti témájú munkáknak olyan aktualitása lenne, mint Kiss László Égnek legszebb ajándéka. Barangolás a himlö elleni védöoltás magyarországi kultúrtörténetében címü kötetének. A könyv időszerüségének oka pedig nem más, mint hogy a modern társadalom különböző csoportjai egyre-másra kérdőjelezik meg a fertőző betegségek elleni védőoltások indokoltságát, ugyanakkor folyamatosan jelennek meg hírek arról is, hogy az átoltottság csökkenésével egyes, az oltásoknak köszönhetően szinte feledésbe merült ragályos betegségek újra szedik áldozataikat Európában. Úgy tünik, időről időre valóban érdemes feleleveníteni, a közgondolkodásba újra beemelni azt a heroikus küzdelmet, amelyet az emberiség története folyamán a fertőző betegségek ellen folytatott. Dr. Kiss László orvos, orvostörténész, aki a pozsonyi Comenius Egyetem Orvosi Karán 1975-ben szerzett oklevelet, és aki az 1980as évektől kezdődően a gyógyító munka mellett az orvostörténeti kutatásoknak is müvelője, orvos- és müvelődéstörténeti szempontokat ötvözve, olvasmányos előadásban tárja fel olvasói előtt a múlt tudományos vívmányainak küzdelmes mindennapjait.

Elsőként a fertőző betegségek közül a fekete himlö, vagy ahogyan csak egyszerủen nevezték, a himlő elleni szervezett küzdelem körvonalazódott Európában, mely küzdelem gyökerei a távoli múltba nyúlnak vissza. Kínában ugyanis már az időszámításunk előtti időben megfigyelték, hogy azok a szerencsés betegek, akik túlélik a fertőzést, többé nem betegszenek meg. Ebben a korban figyelték meg azt is, hogy a kisebb mértékü megfertőződés is védelmet nyújt. Ezért Kínában gyakorlat volt, hogy a megbetegedett emberek himlőhólyagjának váladékát, vagy porát egészséges emberek orrnyálkahártyájára juttatták. Az így, enyhébb lefolyású himlőben megbetegedett emberek védettek lettek a további fertőzésekkel szemben. Az egészséges emberek szándékos megfertőzése Törökország területén is gyakorlat volt, ám itt a bőr megkarcolásával juttatták be a kórokozókat a szervezetbe. A hagyomány szerint Mary Worthley Montagu (1689-1762) 1718 körül hozta Európába ezt az eljárást, amit varioláció névvel illet a szakma.

A himlőoltás felfedezése Edward Jenner (1749-1823) nevéhez füződik, aki egy népi megfigyelésből kiindulva fejlesztette ki eljárását, amit ma vakcinációként ismerünk. Történt ugyanis, hogy meghallotta egy tehenészlány kijelentését, miszerint a lány már nem kaphatja meg a himlőt, mivel ő már kigyógyult a tehénhimlőből. Ezen a nyomon elindulva, Jenner kísérleteinek köszönhetően született meg a vakcináció, ami 1796-ban indult hódító útjára Európában. Hatalmas társa- 
dalmi ellenállást kellett leküzdeni ahhoz, hogy az embereket rávegyék, oltassák be gyermekeiket himlő ellen. A kötelező himlőoltást 1875-től kezdték bevezetni a különböző országokban. A kötelező védőoltásoknak köszönhetően a betegség a 20. század végére megszünt.

A variolizáció, majd a himlőoltás elterjedésének története majdnem minden európai országban hasonlóságot mutat, de természetesen megvannak egy-egy ország jellegzetes adottságai, amelyek mégis egyedivé teszik a körülményeket. Így volt ez Magyarországon is. A kontinens első feljegyzett variolációs kísérlete Raymann János (1690-1770) eperjesi orvos nevéhez füződik, akinek tette jobbára ismeretlen maradt a kortársak számára. Fél évszázadnak kellett eltelnie ahhoz, hogy Rayman variolációs kísérlete a szakirodalomba kerüljön. A Monarchiában csak 1768-tól tekintették az oltást elfogadottnak, ugyanis ebben az évben oltatta be Mária Terézia két gyermekét, amikor Bécs városában újra felütötte fejét a himlö.

A himlőoltás lehetősége, híre és gyakorlata csak lassan terjedt a korabeli Európában, így hazánkban is. Az első magyar nyelven íródott könyv, melyben az orvosok, seborvosok és borbélyok a himlőoltás megelőző hatásáról, az oltás mechanizmusáról olvashattak, Benkő Sámuel (1747-1825) Borsod vármegye orvosa $A$ hójagos himlöröl való tanácsadás címü kötete volt, mely 1781-ben jelent meg Kassán. Az egyik első magyar vakcináló Beke Márton (megh. 1806) győri gyakorlóorvos volt. 1801-ben a pesti orvosi kar indítványozta, hogy a Monarchia minden országában nevezzenek ki egy-egy orvost, akik a vakcináció rendszabályában megegyeznének, és a tehénhimlővel való beoltást az állam nyilvánosan vezesse be. Ez azonban még váratott magára, Magyarországon a védőoltást az 1876-os közegészségügyi törvény tette kötelezővé.

A himlő elleni védekezés és megelőzés elterjesztése a kezdeti időkben csupán az orvosok ügye volt. Az oltóanyag beszerzése mellett nekik kellett megtalálni a módját annak is, hogyan juttassák el az információt az emberekhez, hogyan ösztönözzék őket arra, hogy beolttassák gyermekeiket a gyilkos kór ellen. Már a kezdetekben használták a sajtó nyilvánosságát, mely hatékony, ugyanakkor ebben a korban még elég behatárolt célközönséget elérő eszköznek számított. Így az eredményesség növelése érdekében az orvosok az egyházakat is bevonták a felvilágosításba. Számos prédikáció maradt fenn, melyben a helyi papok a himlő elleni védőoltás beadására ösztönözték a szülőket.

Kiss László orvostörténész aprólékos munkával göngyölíti fel a hazai és nemzetközi történéseket a himlőoltásra vonatkozóan. Külön erénye a könyvnek, hogy a hazai eseményeket nem önmagukban láttatja, hanem nemzetközi kontextusba helyezi őket, ugyanakkor rávilágít olyan eseményekre, összefüggésekre is, melyekről hajlamosak lehetünk megfeledkezni, amikor nemzetközi összehasonlítást végzünk. İgy világlik meg például az a tény, miért volt könnyebb Angliában támogatást találni a himlő elleni oltás elterjesztésére. Mary Worthley Montagu nem 
mást, mint a királynőt kereste és győzte meg az oltás helyességéről. A Kiss László adatai szerint 1721-töl variolizáló Raymannak esélye sem lehetett - különösen a Rákóczi-féle felkelés után nem sokkal - a bécsi uralkodóházig, a Habsburgokig jutnia, és támogatást kérni az uralkodótól.

A kötet azonban nemcsak arra vállalkozott, hogy felidézze a régmúlt korokat, hanem arra is, hogy kiegészítse, újraértékelje, új adatokkal bővítse az eddigi ismereteket. Kiss doktor felkutatta és összevetette, ahol lehetett, pontosította a különböző szakirodalmi müvekben fellelhető adatokat. A könyv nagy erénye ez, ugyanakkor itt fedezhető fel nagy hiányossága is. A szerző ugyanis szinte csak másodlagos forrásból dolgozik, és a levéltári kutatások hiányoznak a müből.

Az alapos levéltári kutatás minden bizonnyal tartogat még meglepetéseket a himlőoltás kultúrtörténetét illetően, különösen, ha a keleti országrész és Erdély levéltáraiban e témában fellelhető, még lappangó adatok is egyszer napvilágra kerülnek majd.

(Kiss László: Égnek legszebb ajándéka. Barangolás a himlö elleni védöoltás magyarországi történetében. Budapest: Magyar Tudománytörténeti és Egészségtudományi Intézet, 2017)

Szabó Katalin

$\mathrm{PhD}$, főmuzeológus Semmelweis Orvostörténeti Múzeum 